\title{
A Study of Spirituality and Home Environment among Various Religious Group
}

\author{
Dr. Rajesh B. Shirsath ${ }^{1}$
}

\section{ABSTRACT}

The aim of present study was to find out differences of various religious groups of college students on spirituality and home environment. An experiment was conducted on 100 college student included that Hindu - 25, Muslim- 25, Buddhist - 25 and Christian - 25. One way ANOVAs used for statistical interpretation. To measure spirituality of the subjects Spirituality Scale (Biswas \& Biswas, 2006) and Perceived home environment the Home Environment Inventory (HEI) was used for data collection. Analysis by ONE-way ANOVA showed that there is significant difference of spirituality among various religious groups of college students. There will be significant difference of home environment among various religious groups of college students.

Keywords: Spirituality, Home Environment, Various Religious

Spirituality is the praxis and process of personal transformation, either in accordance with traditional religious ideals, or, increasingly, oriented on subjective experience and psychological growth independently of any specific religious context. In a more general sense, it may refer to almost any kind of meaningful activity or blissful experience. There is no single, widely-agreed definition for the concept, and the term may be applied to a wide variety of practices.

There is no single, widely-agreed definition of spirituality. Surveys of the definition of the term, as used in scholarly research, show a broad range of definitions, with very limited similitude. According to Waaijman, the traditional meaning of spirituality is a process of re-formation which "aims to recover the original shape of man, the image of God. To accomplish this, the reformation is oriented at a mold, which represents the original shape: in Judaism the Torah, in Christianity Christ, in Buddhism Buddha, in the Islam Muhammad."

In modern times the emphasis is on subjective experience. It may denote almost any kind of meaningful activity or blissful experience. It still denotes a process of transformation, but in a context separate from organized religious institutions, termed "spiritual but not religious".

\footnotetext{
${ }^{1}$ Assistant Professor, Kala Mahavidyalaya, Nandurghat, Tq. Kaij, Dist. Beed. (MH)
} 


\section{A Study of Spirituality and Home Environment among Various Religious Group}

Houtman and Aupers suggest that modern spirituality is a blend of humanistic psychology, mystical and esoteric traditions and eastern religions.

Waaijman points out that "spirituality" is only one term of a range of words which denote the praxis of spirituality. Some other terms are "Hasidism, contemplation, kabbala, asceticism, mysticism, perfection, devotion and piety".

Spirituality is something that's often debated and commonly misunderstood. Many people confuse spirituality with religion and so bring pre-existing beliefs about the impact of religion to discussions about spirituality. Though all religions emphasise spirituality as being an important part of faith, it's possible to be 'spiritual' without necessarily being a part of an organised religious community.

In a similar way that religion might guide you to find your Spirituality and religion can be hard to tell apart but there are some pretty defined differences between the two. Religion is a specific set of organised beliefs and practices, usually shared by a community or group. Spirituality is more of an individual practice and has to do with having a sense of peace and purpose. It also relates to the process of developing beliefs around the meaning of life and connection with others. One way that might help you to understand the relationship between spirituality and religion is imagine a game of football. The rules, referees, other players, and field markings help guide you as you play the game spirituality. Kicking the ball around a park, without having to play on the field or with all the rules and regulations, can also give you fulfillment and fun and still expresses the essence of the game, similar to spirituality in life.

Environmental psychology addresses environmental problems such as density and crowding, noise pollution, sub-standard living, and urban decay Noise increases environmental stress. Although it has been found that control and predictability are the greatest factors in stressful effects of noise; context, pitch, source and habituation are also important variables [3]. Environmental psychologists have theorized that density and crowding can also have an adverse effect on mood and may cause stress-related illness. Environmental psychology is a direct study of the relationship between an environment and how that environment affects its inhabitants. Specific aspects of this field work by identifying a problem and through the identification of said problem, discovering a solution. Therefore it is necessary for environmental psychology to be problem oriented. The problems identified by environmental psychologists affect all members of society. These problems can be anything from the psychological effects of urban crowding to the architectural design of public schools and extend from the public arena into the individual household.

\section{REVIEW OF LITERATURE:}

Jon C. Dalton, et. al. (2006). There is considerable evidence that a growing number of college students today are engaged in many new forms of spiritual search and practice. The forms and patterns of contemporary college student spirituality are diverse and multifaceted and not yet 
well understood or documented. Consequently, there is much to be learned about this recent development in college student spirituality in order to determine its meaning and importance for today's college students as well as for the educational and student developmental efforts of colleges and universities. This article reports on the findings of the authors' research into the contemporary forms and patterns of college student spirituality and offers an analysis and discussion of the implications of these findings for colleges and universities. The authors examine in particular the behaviors and involvements of college students related to spiritual search activities and what some colleges and universities are doing to respond to this important student trend.

Jaon Solomon (2003). The value of including a kind of spirituality in science education, and especially in environmental education, is taken as a given. The work on which the argument is based starts from the young child's use of the senses which are so acute at primary school age, but also stimulates the asking of 'big questions' which seem spiritual in a sense that is examined here. A fragmented historical exploration shows pre-enlightenment educators encouraging the use of the senses, whereas Descartes, Hume, and Locke all argued against it. Later Husserl and Merleau-Ponty took a phenomenological stance which sometimes saw wonder, based on perception, as seriously opposed to scientific curiosity or explanation. The paper ends with an attempt to reconcile the phenomenological with the scientific, suggesting a perception of play which includes curiosity, and of the environment based on the sensory. A brief look at the development of environmental attitudes over the last century shows an increasing use of the affective along with the scientific. A closing consideration of spirituality in the Gaia hypothesis is illustrated by an extract from metaphysical poetry.

Rani Mohanraj and Latha, (2005). The study aimed to investigate the relationship between family environment, the home adjustment and academic achievement in adolescents. The adolescents (106-Boys and 86 girls) were assessed using the Moos and Moos Family Environment Scale and Bell's adjustment inventory. Academic scores were taken from the school records. Family environment appeared to influence home adjustment as well as academic performance. The majority of the sample perceived their family as cohesive, organized, achievement oriented and emphasizing on moral - religious issue with minimal conflict. Cohesion, conflict, control, intellectual - cultural orientation and independence in the family environment influenced home adjustment. Academic performance was significantly related to independence and conflict domains of family environment. Boys and girls differed in perception of the home and environment.

\section{OBJECTIVE OF THE STUDY:}

- To study the spirituality among various religious groups of college students.

- To study the home environment among various religious groups of college students.

- To search the relationship between spirituality and home environment. 


\section{HYPOTHESIS OF THE STUDY:}

- There will be significant difference of spirituality among various religious groups of college students.

- There will be significant difference of home environment among various religious groups of college students.

- There will be positive correlation between spirituality and home environment.

\section{METHODOLOGY:}

\section{Sample:}

Total sample consists of 100 subjects, randomly selected from Marathwada region (25 Hindu, 25 Buddhists, 25 Muslim and 25 Christian). The age level and educational status of the subjects were controlled to a certain extent i.e., age ranges between 18-25 years, all graduate students were selected from urban population.

\section{Variables:}

\section{Independent variable:}

- Religious groups (i.e., Hindu, Buddhist, Muslim and Christian)

\section{Dependent variables:}

- Spirituality

- Home environment

\section{Design:}

In this study one way design was used. Religious Groups as independent variables varied at four levels. One-way factorial design was used. And to study the relation between modernization and religiosity, modernization and locus of control, religiosity and locus of control further the correlation design was used.

\section{Religious Groups (A)}

\begin{tabular}{cc|c|c|}
\cline { 2 - 3 } Hindu & Buddhist & Muslim & Christian \\
(A1) & (A2) & (A3) & (A4)
\end{tabular}

\section{Tool:}

\section{Spirituality Scale:}

To measure spirituality of the subjects Spirituality Scale (Biswas \& Biswas, 2006) was used. Spirituality items for this measure were developed after reviewing the work of Indian spiritualist leaders and philosophers (e.g., Radhakrishana, Vivekananda, Maharishi Mahesh Yogi etc.). Four aspects of Indian spirituality were found which shares commonality with others spiritual practices. They included centrality of God, ethical and moral values, and the cyclical nature of pain and pleasure in one's life and power of meditation. Based on spiritual literature, twenty two statements were written which described different aspect of spirituality in Indian context. These statements were presented to seven different individuals who were knowledgeable about Indian spiritual tradition and also practiced different methods of spiritual practices. Based on their feedback one item is dropped and few items were reworded to make it more meaningful. Thus, 
the final instrument consisted of 21 statements. All items were rated on four point rating scale ranging from strongly agree (4) to strongly disagree (1). The possible score range on the scale can be 21 to 84 . The cronback alpha for the measure was 0.84 .

\section{Home Environment Inventory (HEI):}

To measure the first dependent variable i.e. Perceived home environment the Home Environment Inventory (HEI) was used. HEI contains 100 items related to ten dimensions of home environment. The dimension are - A- control, -B protectiveness, -C- Punishment, -D conformity, E- Social Isolation, F- Reward, G- Deprivation of Privileges, H- Nurturance, IRejection, and J- Permissiveness. Each dimension has ten items belonging to it. The instrument requires pupils to tell the frequency with which a particular parent child interaction behaviour has been observed by them in their homes, i.e. he/she requested to tell whether a particular parental behaviour (as mentioned in an item) Occurs - 'Mostly', 'Often', 'Sometime', 'Lest', and 'Never'. The manual reports that the test-retest reliability of the home environment inventory was administered to 113 students studying in intermediate classes of five schools. Split half reliabilities were worked out separately for all the ten dimensions of home environment. The split half reliabilities (Corrected for length) for various dimension of home environment mention high reliability.

\section{RESULT AND DISCUSSION:}

Table No. 1 Summary of one way ANOVA for Dependent Variable Spirituality

\begin{tabular}{|c|c|c|c|c|c|}
\hline Source & $\begin{array}{c}\text { Type III } \\
\text { Sum of } \\
\text { Squares }\end{array}$ & df & $\begin{array}{c}\text { Mean } \\
\text { Square }\end{array}$ & F & Sig. \\
\hline $\begin{array}{c}\text { Religious } \\
\text { group }\end{array}$ & 2804.11 & 3 & 934.70 & 8.95 & .000 \\
\hline Error & 10016.48 & 96 & 104.33 & & \\
\hline Total & 306693.00 & 100 & & & \\
\hline $\begin{array}{c}\text { Corrected } \\
\text { Total }\end{array}$ & 12820.59 & 99 & & & \\
\hline
\end{tabular}

Table 1 show that the significant differences for intendment variable religious groups. Hindu, Buddhist, Muslim and Christian religious groups $(\mathrm{F}=8.95$ for $\mathrm{df}=3$, $96 \mathrm{P}<0.01)$ on spiriatulity. Result concluded that the hypothesis no. 1 "There will be significant difference of spirituality among various religious groups of college students.” 
Table No. 2 Mean and SD value for religious groups on Spirituality

\begin{tabular}{|l|r|r|r|}
\hline Religious group & Mean & \multicolumn{1}{|c|}{$\begin{array}{c}\text { Std. } \\
\text { Deviation }\end{array}$} & \multicolumn{1}{c|}{ N } \\
\hline Hindu & 60.80 & 9.66 & 25 \\
\hline Buddist & 48.52 & 10.85 & 25 \\
\hline Muslim & 49.52 & 9.32 & 25 \\
\hline Christian & 58.00 & 10.92 & 25 \\
\hline Total & 54.21 & 11.37 & 100 \\
\hline
\end{tabular}

The above result table no.2 and figure no.1 illustrates the mean values of various religious groups on the dependent variable spirituality. The mean values show that Hindu religious group scored ( $M=60.80)$, Buddhist religious group scored $(M=48.52)$, Muslim religious group scored $($ Mean $=49.52)$ and Christian religious group scored (Mean $=58.00)$. Above mean scored indicated that the Hindu religious groups college students more spiritual than the Buddhist, Muslim and Christian religious groups of college students.

A growing numbers of college students are participating in a variety of activities that, in one form or another, provide gateways to the inner life of reflection and self-examination (Higher Education Research Institute, 2004; Mooney, 2005; Gallup, 1998; CRRUCS/Gallup, 2003; Dalton, 2003). Perhaps the most powerful metaphors for the spirituality movement among college students today are "inward journey" and "quest." When college students write or are asked about spirituality, they consistently describe it as a journey or quest that takes them inward into the unknown, unexamined regions of their inner lives. Sharon Parks (2000) describes the inner search of youth as a quest to answer the "big" questions of life. A College student takes many paths on their inward journeys. Some make their spiritual searches within the context of a religious faith orientation. The spiritual practices in which they engage are directly connected to the community beliefs, rituals, symbols, and meanings of their personal faith tradition. Other students choose to explore paths outside the boundaries of a particular faith tradition and engage in spiritual searches that have little if any connection to any specific religious orientation. What is striking about the contemporary spirituality movement among college students is the wide variety of spiritual practices that students engage in and how receptive they are to exploring new forms of spiritual searching. For reasons that are not fully understood at this time, college students today seem to be very open and motivated to tackling the big questions that young people typically face during the college years. 
Table No. 3 Summary of one way ANOVA for Dependent Variable Home-environment.

\begin{tabular}{|c|c|c|c|c|c|}
\hline Source & $\begin{array}{c}\text { Type III } \\
\text { Sum of } \\
\text { Squares }\end{array}$ & df & $\begin{array}{c}\text { Mean } \\
\text { Square }\end{array}$ & F & Sig. \\
\hline $\begin{array}{c}\text { Religious } \\
\text { group }\end{array}$ & 33269.36 & 3 & 11089.78 & 4.46 & .006 \\
\hline Error & 238480.48 & 96 & 2484.17 & & \\
\hline Total & 4599814.00 & 100 & & & \\
\hline $\begin{array}{c}\text { Corrected } \\
\text { Total }\end{array}$ & 271749.84 & 99 & & & \\
\hline
\end{tabular}

Table no.3 show that the significant differences of home environment for intendment variable religious groups. Hindu, Buddhist, Muslim and Christian religious groups $(\mathrm{F}=4.46$ for $\mathrm{df}=3$, $96 \mathrm{P}<0.01$ ) on home environment. Result concluded that the hypothesis no. 2 "There will be significant difference of home environment among various religious groups of college students." Table No. 4 Mean and SD value for religious groups on Home environment

\begin{tabular}{|c|c|c|c|}
\hline $\begin{array}{c}\text { Religious } \\
\text { group }\end{array}$ & Mean & $\begin{array}{c}\text { Std. } \\
\text { Deviation }\end{array}$ & N \\
\hline Hindu & 224.32 & 48.62 & 25 \\
\hline Buddhist & 226.04 & 45.87 & 25 \\
\hline Muslim & 182.12 & 49.91 & 25 \\
\hline Christian & 199.68 & 54.56 & 25 \\
\hline Total & 208.04 & 52.39 & 100 \\
\hline
\end{tabular}

The above result table no.4 and figure no.2 show the mean values of various religious groups on the dependent variable home environment. The mean values show that Hindu religious group scored ( $M=224.32)$, Buddhist religious group scored $(M=226.04)$, Muslim religious group scored $($ Mean $=182.12)$ and Christian religious group scored (Mean $=199.68)$. Above mean scored indicated that the Buddhist and Hindu religious groups college students more positive home environment than the Muslim and Christian religious groups of college students.

\section{CONCLUSION:}

- There is significant difference of spirituality among various religious groups of college students. The Hindu religious groups college students more spiritual than the Buddhist, Muslim and Christian religious groups of college students.

- There will be significant difference of home environment among various religious groups of college students. The Buddhist and Hindu religious groups college students more 


\section{A Study of Spirituality and Home Environment among Various Religious Group}

positive home environment than the Muslim and Christian religious groups of college students.

\section{REFERENCE:}

Broota K. D.(2002), Experimental Design in Behavioural Research, New Delhi; New Age International (P) Lit. Publisher.

Frame, M. W. (2003). Integrating religion and spirituality into counseling: A comprehensive approach. Pacific Grove, CA: Brooks/Cole.

Jon C. Dalton, David Eberhardt, Jillian Bracken, and Keith Echols. (2006). Inward Journeys: Forms and Patterns of College Student Spirituality. Journal of College \& Character, volume - vii, no. 8.

Jaon Solomon (2003) Spirituality in science education: studying the environment, Interdisciplinary science review, Volume 28, Issue 4, pp. 251-258.

Jones, S. L., Watson, E. J., \& Wolfram, T. J. (1992). Results of the Rech conference survey on religious faith and professional psychology. Journal of Psychology and Theology, 20, 147158.

Rani Mohanraj and Latha, (2005). Perceived Family Environment in Relation to Adjustment and Academic Achievement, Journal of the Indian Academy of Applied Psychology, Vol. 31, No.1-2, 18-23.

Satu Elo (2006), A theory of Environmental Supporting The Well-being of home Dwelling Elderly, International Journal of circumpolar Health Val. 65.

Sharma Reena and Nigam Vibha, (2003) Manual For Home Environment Scale, Agra: Rakhi Prakashan Agra, India. 